\title{
Front Matter: Volume 8871
}

, "Front Matter: Volume 8871," Proc. SPIE 8871, Satellite Data Compression, Communications, and Processing IX, 887101 (14 October 2013); doi: $10.1117 / 12.2048436$

SPIE Event: SPIE Optical Engineering + Applications, 2013, San Diego, California, SPIE. United States 


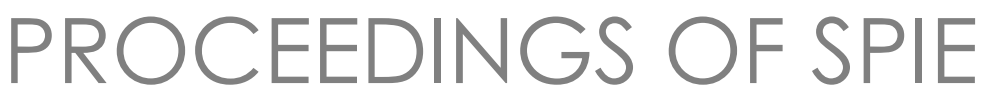

\title{
Satellite Data Compression, Communications, and Processing IX
}

\author{
Bormin Huang \\ Antonio J. Plaza \\ Chein-I Chang \\ Editors
}

26-27 August 2013

San Diego, California, United States

Sponsored and Published by

SPIE 
The papers included in this volume were part of the technical conference cited on the cover and title page. Papers were selected and subject to review by the editors and conference program committee. Some conference presentations may not be available for publication. The papers published in these proceedings reflect the work and thoughts of the authors and are published herein as submitted. The publisher is not responsible for the validity of the information or for any outcomes resulting from reliance thereon.

Please use the following format to cite material from this book:

Author(s), "Title of Paper," in Satellite Data Compression, Communications, and Processing IX, edited by Bormin Huang, Antonio J. Plaza, Chein-I Chang, Proceedings of SPIE Vol. 8871 (SPIE, Bellingham, WA, 2013) Article CID Number.

ISSN: 0277-786X

ISBN: 9780819497215

Published by

SPIE

P.O. Box 10, Bellingham, Washington 98227-0010 USA

Telephone +1 3606763290 (Pacific Time) · Fax +1 3606471445

SPIE.org

Copyright (C) 2013, Society of Photo-Optical Instrumentation Engineers.

Copying of material in this book for internal or personal use, or for the internal or personal use of specific clients, beyond the fair use provisions granted by the U.S. Copyright Law is authorized by SPIE subject to payment of copying fees. The Transactional Reporting Service base fee for this volume is $\$ 18.00$ per article (or portion thereof), which should be paid directly to the Copyright Clearance Center (CCC), 222 Rosewood Drive, Danvers, MA 01923. Payment may also be made electronically through CCC Online at copyright.com. Other copying for republication, resale, advertising or promotion, or any form of systematic or multiple reproduction of any material in this book is prohibited except with permission in writing from the publisher. The CCC fee code is 0277-786X/13/\$18.00.

Printed in the United States of America.

Publication of record for individual papers is online in the SPIE Digital Library.

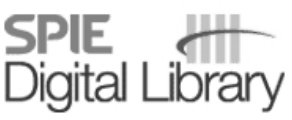

SPIEDigitallibrary.org

Paper Numbering: Proceedings of SPIE follow an e-First publication model, with papers published first online and then in print and on CD-ROM. Papers are published as they are submitted and meet publication criteria. A unique, consistent, permanent citation identifier (CID) number is assigned to each article at the time of the first publication. Utilization of CIDs allows articles to be fully citable as soon as they are published online, and connects the same identifier to all online, print, and electronic versions of the publication. SPIE uses a six-digit CID article numbering system in which:

- The first four digits correspond to the SPIE volume number.

- The last two digits indicate publication order within the volume using a Base 36 numbering

system employing both numerals and letters. These two-number sets start with 00, 01, 02, 03, 04, $05,06,07,08,09,0 A, 0 B \ldots 0 Z$, followed by 10-1Z, 20-2Z, etc.

The CID Number appears on each page of the manuscript. The complete citation is used on the first page, and an abbreviated version on subsequent pages. Numbers in the index correspond to the last two digits of the six-digit CID Number. 


\section{Contents}

vii Conference Committee

\section{SESSION 1 COMPRESSION AND COMMUNICATION I}

887102 Hyperspectral data compression using a Wiener filter predictor [8871-1]

P. V. Villeneuve, S. G. Beaven, A. D. Stocker, Space Computer Corp. (United States)

887103 An encoder rate control method for unidirectional distributed video coding [8871-2] J. Song, P. Shen, L. Zhang, K. Wang, Xidian Univ. (China)

887104 Performance analysis of 2D asynchronous hard-limiting optical code-division multiple access system through atmospheric scattering channel [8871-3]

Y. Zhao, X. Zhong, D. Wu, Y. Zhang, G. Ren, Z. Wu, Harbin Institute of Technology (China)

887105 Lossless compression of hyperspectral images using adaptive edge-based prediction [8871-4]

K. Wang, L. Wang, H. Liao, J. Song, Y. Li, Xidian Univ. (China)

887106 Improving multispectral satellite image compression using onboard subpixel registration [8871-5]

M. Albinet, R. Camarero, Ctr. National d'Études Spatiales (France); M. Isnard, Thales

Services (France); C. Poulet, J. Perret, EREMS (France)

\section{SESSION 2 IMAGE CLASSIFICATION}

887107 Fast implementation of neural network classification [8871-6]

G. Seo, J. Ok, C. Lee, Yonsei Univ. (Korea, Republic of)

887108 An efficient classification by signal subspace projection and partial filtering for hyperspectral images [8871-7]

L. Chang, Z.-S. Tang, H.-S. Hung, National Taiwan Ocean Univ. (Taiwan); Y.-L. Chang, National Taipei Univ. of Technology (Taiwan)

8871 OA Saline-alkali land classification using MODIS data In Western Jilin Province, China [8871-9] L. Gu, R. Ren, Jilin Univ. (China); J. Cao, Changchun Institute of Optics, Fine Mechanics and Physics (China); J. Sun, Jilin Univ. (China) 
$8871 \mathrm{OB} \quad$ Multi-watermarking scheme for copyright protection and content authentication of DubaiSat-1 satellite imagery [8871-10]

S. Al-Mansoori, Emirates Institution for Advanced Science and Technology (United Arab Emirates); A. Kunhu, Khalifa Univ. of Science, Technology and Research (United Arab Emirates)

8871 OC Anomaly-specified virtual dimensionality [8871-11]

S.-Y. Chen, D. Paylor, C.-I. Chang, Univ. of Maryland, Baltimore County (United States)

$8871 \mathrm{OE} \quad$ Spatial correlations constrained sparse unmixing of hyperspectral image using adapting Markov random fields [8871-13]

J. Li, Y. Li, X. Wu, J. Liu, K. Wang, K. Liu, Xidian Univ. (China)

8871 OF Early warning of malaria at Bikaner, Rajasthan in India using AVHRR-based satellite data [8871-14]

L. Roytman, M. Nizamuddin, K. Akhand, The City Univ. of New York (United States);

F. Kogan, M. Goldberg, National Oceanic and Atmospheric Administration (United States)

\section{SESSION 4 HIGH-PERFORMANCE COMPUTING}

88710 An FPGA implemented bridge over water recognition for an image evaluation on-board of satellites [8871-17]

S. Beulig, M. v. Schönermark, F. Huber, Deutsches Zentrum für Luft- und Raumfahrt e.V. (Germany)

8871 OK A novel VLSI architecture for pixel purity index algorithm [8871-19]

F. Yi, J. Guo, Y. Li, Xidian Univ. (China); B. Huang, Univ. of Wisconsin-Madison (United States)

\section{SESSION 5 IMAGE PROCESSING II}

$8871 \mathrm{OM}$ Fusion of hyperspectral remote sensing data for near real-time monitoring of microcystin distribution in Lake Erie [8871-21]

B. Vannah, N. Chang, Univ. of Central Florida (United States)

$88710 N \quad$ Enhancing DubaiSat-1 satellite imagery using a single image super-resolution [8871-22] S. Al-Mansoori, Emirates Institution for Advanced Science and Technology (United Arab Emirates); A. Kunhu, Khalifa Univ. of Science, Technology and Research (United Arab Emirates)

$887100 \quad$ High-resolution satellite image recovery by modulation transfer function (MTF) compensation method using phase congruency estimation [8871-23]

X. Shao, H. Yang, S. Zhang, Z. Jin, J. Du, Xidian Univ. (China) 
8871 OP Progressive band processing of anomaly detection [8871-24]

R. Schultz, U.S. Naval Academy (United States); S.-Y. Chen, Univ. of Maryland, Baltimore County (United States); Y. Wang, Harbin Engineering Univ. (United States); C. Liu, China Agricultural Univ. (China); C.-I. Chang, Univ. of Maryland, Baltimore County (United States)

$88710 Q$ Quality control of satellite-retrieved sea surface temperature [8871-25]

Q. Tu, Zhejiang Univ. (China) and The Second Institute of Oceanography, SOA (China);

D. Pan, Z. Hao, H. Huang, F. Gong, The Second Institute of Oceanography, SOA (China);

D. Shi, State Oceanic Administration (China)

\section{SESSION 6 COMPRESSION AND COMMUNICATION II}

8871 OR A fast forward/backward semi-blind channel estimation for MIMO STC-OFDM systems [8871-26]

L. Chang, C.-M. Cheng, Z.-S. Tang, National Taiwan Ocean Univ. (Taiwan)

8871 OS Hyperspectral image compression and target detection using nonlinear principal component analysis [8871-28]

Q. Du, W. Wei, B. Ma, N. H. Younan, Mississippi State Univ. (United States)

8871 OT A normal laser warning system model based on Hadamard Transform [8871-29]

F. Liu, X. Shao, P. Han, Xidian Univ. (China); H. Chang, Weihai Vocational College (China)

POSTER SESSION

8871 OU Digital transceiver design for two-way AF-MIMO relay systems with imperfect CSI [8871-30]

C.-C. Hu, Y.-F. Chou, K.-H. Chen, National Chung Cheng Univ. (Taiwan)

Author Index 
Proc. of SPIE Vol. $8871887101-6$

Downloaded From: https://www.spiedigitallibrary.org/conference-proceedings-of-spie on 26 Apr 2023 Terms of Use: https://www.spiedigitallibrary.org/terms-of-use 


\title{
Conference Committee
}

\author{
Program Track Chair
}

Allen H.-L. Huang, University of Wisconsin-Madison (United States)

Conference Chairs

Bormin Huang, University of Wisconsin-Madison (United States)

Antonio J. Plaza, Universidad de Extremadura (Spain)

Chein-I Chang, University of Maryland, Baltimore County (United States)

Conference CoChairs

Chulhee Lee, Yonsei University (Korea, Republic of)

Yunsong Li, Xidian University (China)

Shen-En Qian, Canadian Space Agency (Canada)

Conference Program Committee

Saeed H. Al-Mansoori, Emirates Institution for Advanced Science and Technology (United Arab Emirates)

Philip E. Ardanuy, Raytheon Intelligence and Information Systems (United States)

Roberto Camarero, Centre National d'Éłudes Spatiales (France)

Lena Chang, National Taiwan Ocean University (Taiwan)

Ni-Bin Chang, University of Central Florida (United States)

Yang-Lang Chang, National Taipei University of Technology (Taiwan)

Qian Du, Mississippi State University (United States)

Samuel D. Gasster, The Aerospace Corporation (United States)

Mitchell D. Goldberg, National Oceanic and Atmospheric Administration (United States)

Lingjia Gu, Jilin University (China)

Tung-Ju Hsieh, National Taipei University of Technology (Taiwan)

Allen H.-L. Huang, University of Wisconsin-Madison (United States)

Felix Huber, Deutsches Zentrum für Luft- und Raumfahrt e.V. (Germany)

Xiaojie Li, Northeast Institute of Geography and Agroecology (China)

Sebastian Lopez Suarez, Universidad de Las Palmas de Gran Canaria (Spain)

Enrico Magli, Politecnico di Torino (Italy)

Jarno Mielikainen, University of Eastern Finland (United States)

Daniela I. Moody, Los Alamos National Laboratory (United States)

Javier Plaza, Universidad de Extremadura (Spain)

Jordi Portell de Mora, Universitat de Barcelona (Spain)

Jeffery J. Puschell, Raytheon Space and Airborne Systems (United States)

Leonid Roytman, The City College of New York (United States)

Xiaopeng Shao, Xidian University (China) 
Yuliya Tarabalka, University of Iceland (Iceland)

Carole Thiebaut, Centre National d'Études Spatiales (France)

Pierre V. Villeneuve, Space Computer Corporation (United States)

Raffaele Vitulli, European Space Research and Technology Center (Netherlands)

Maria F. von Schoenermark, Universität Stuttgart (Germany)

Shih-Chieh Wei, Tamkang University (Taiwan)

Zhang Ye, Harbin Institute of Technology (China)

Session Chairs

1 Compression and Communication I

Bormin Huang, University of Wisconsin-Madison (United States)

2 Image Classification

Saeed H. Al-Mansoori, Emirates Institution for Advanced Science and Technology (United Arab Emirates)

3 Image Processing I

Yunsong Li, Xidian University (China)

4 High-performance Computing

Qian Du, Mississippi State University (United States)

Ye Zhang, Harbin Institute of Technology (China)

5 Image Processing II

Chulhee Lee, Yonsei University (Korea, Republic of)

6 Compression and Communication II

Ni-Bin Chang, University of Central Florida (United States) 